\title{
STRUKTUR PUISI DALAM KUMPULAN PUISI SESUDAH ZAMAN TUHAN DAN PEMBELAJARANNYA DI SMP
}

\author{
Yeyen Yusniar $^{1)}$ M.Windi Wiranda ${ }^{2)}$ \\ ${ }^{1)}$ 2) Program Studi Pendidikan Bahasa Indonesia \\ Universitas Islam Ogan Komering Ilir Kayuagung \\ 1)yeyenyusniar@gmail.com ${ }^{2}$ Windiwiranda@gmail.com
}

\begin{abstract}
Abstrak
Penelitian ini bertujuan untuk mendeskripsikan struktur puisi dalam kumpulan puisi Sesudah Zaman Tuhan dan pembelajarannya di SMP. Penelitian ini menggunakan pendekatan struktural dan metode deskriptif kualitatif. Dalam penelitian ini teori yang digunakan ialah teori Kosasih yaitu struktur puisi meliputi batin dan fisik. Selanjutnya, hasil penelitian diperoleh penggunaan bahasa, kondisi atau psikologis dan latar belakang dalam puisi-puisi Sesudah Zaman Tuhan sangat tepat dan sesuai apabila dijadikan bahan ajar. Dalam pembelajaran, kumpulan puisi sesudah zaman tuhan dapat dijadikan sebagai contoh soal dalam materi pembelajaran, karena dalam setiap puisi-puisinya banyak sekali kata konkret yang membuat siswa mudah dalam memahami puisi.
\end{abstract}

Kata kunci: batin, fisik, pembelajaran, puisi

\section{PENDAHULUAN}

Manusia adalah makhluk yang berbudaya, mempunyai adatistiadat, norma-norma dan ketetuanketentuan dalam menjalani hidup. Manusia dan budaya itu sendiri mempunyai hubungan yang erat dengan karya sastra. Bahkan budaya selalu dikaitkan dengan karya sastra. Sering kali budaya dikatakan bentuk dari sebuah ciptakan yang disebut karya sastra. Bila dilihat secara garis besar karya sastra dibedaan menjadi sastra lama dan sastra modern, sastra lisan dan sastra tulisan, sastra nasional dan sastra regional. Lalu pengertian karya sastra itu sendiri adalah (medium) bahasa (Ratna, 2016:119). Dengan kata lain, karya sastra adalah gaya (bahasa) di antara unsur-unsur pembangunnya. Seiring dengan pernyataan tersebut karya sastra merupakan media karya imajinatif seseorang yang berbentuk indah yang menyiratkan akan emosi, harapan, tujuan, ataupun pesan yang dituangkan dengan gaya bahasa tertentu. Oleh sebab itulah karya sastra menjadi bahan yang menarik untuk dikaji karena karya sastra merupakan medium yang tepat dalam berkomunikasi yang baik. 
Maksudnya adalah penyajian informasi yang berupa sastra berbentuk ekspresi yang positif. Mampu meluapkan semua emosi, rasa takut, keinginan dan lain-lain dalam bentuk positif. Dampak positif itu akan di rasakan oleh penulis ataupun pembacanya. Terutama sastra yang sangat banyak makna ataupun pesan moral yang baik dan disusun dengan kata-kata indah. Karya Sastra yang dimaksudkan tersebut berbentuk karya-karya naratif meliputi, puisi, novel, roman dan sabagainya. Namun, genre puisilah yang akan dipilih oleh peneliti. Karena puisi merupakan karya sastra yang mengutamakan seni atau keindahan dalam meluapkan emosi dengan pesan dan tujuan tertentu.

Seperti pendapat Wirawan, (2016:39) puisi merupakan suatu karya yang ditulis oleh pengarang setelah proses penghayatan atau perenungan terhadap peristiwa yang dialami atau dilihat dengan menggunakan bahasa sebagai media penyampai secara tertulis. Itu berarti puisi bisa menjadi cara yang tepat untuk mengungkapkan semua emosi dan pikiran yang ada dalam benak seseorang. Selain itu, puisi biasanya lebih singkat dari jenis sastra lainnya sehingga tidak menimbulkan kejenuhan ketika membacanya.

Puisi itu sendiri mempunyai struktur secara fisik maupun batin. Struktur fisik merupakan perwujudan atau internal dari puisi, sedangkan struktur batin struktur diluar atau eksternal dari puisi tersebut. Oleh sebab itu, puisi tidak dapat dibuat sembarangan, puisi harus memperhatikan kedua struktur tersebut yang menjadi komponen atau hal penting dalam puisi.

Struktur puisi ini dinyatakan sangat penting karena sebuah puisi terbentuk atau dibangun oleh susunan luar dan dalam. Dimana ada keterkaitan dan saling menunjang antarstruktur tersebut. Apabila suatu karya ditulis demikian, maka dikatagerikan sebagai puisi yang menarik untuk dinikmati. Karangan terikat ini sangat efektif dalam menyampaikan pesan penulis terhadap pembaca. Namun, karya puisi itu harus sampai ke pembaca terlebih dahulu sehingga dapat dibaca. 
Supaya karyanya dapat dibaca oleh pembaca, pengarang biasanya mengabadikannya secara tertulis di buku, kumpulan puisi (ebook) atau wacana online. Selain itu, karya puisi sering di publis di media massa, seperti medsos, media cetak, dan lainnya.

Penulis tidak mengkaji semuanya melainkan hanya satu jenis, yaitu kumpulan puisi (e-book). Kumpulan puisi ini tidak terlalu jauh berbeda dengan buku pada umumnya. Buku elektonik biasanya berbentuk file yang memungkinkan untuk membacanya melalui smardphone maupun laptop. File tersebut dapat dibagikan dengan cepat lewat media sosial. Hal inilah yang membuat smartphone naik daun. Pengguna lebih leluasa berbagi kebahagian atau mencurahkan kesedihan dengan bahasa yang estetik. Selain itu juga, sebagian besar aktifitas manusia kini dilakukan dan dipercepat oleh smardphone.

$\begin{array}{lrr} & \text { Salah-satu aktivitas yang } \\ \text { dapat } & \text { dilakukan } & \text { dengan } \\ \text { menggunakan smardphone } & \text { seperti } \\ \text { yang disampaikan sebelumnya }\end{array}$

adalah membaca; baik membaca berita, pengumuman, informasi, buku, maupun karya sastra. Seperti penjelasan sebelumnya pada penelitian ini karya sastra yang akan dibahas adalah puisi. Puisi termasuk karya sastra dapat menyampaikan Informasi dengan konotasi yang baik dan membuat hati pembacanya merasa damai. Secara tidak langsung, banyak orang yang menggunakan puisi dan merasakan dampak positif. Oleh karena itu, puisi harus diperkenalkan serta dipahami oleh khalayak, dari anakanak sampai dewasa. Cara yang paling efektif memperkenalkan dan memberi pemahaman terhadap puisi ialah melalui pendidikan atau kegiatan pembelajaran.

Untuk memahami puisi diperlukan pembelajaran atau kegiatan belajar-mengajar yang tepat dan bukan kegiatan yang mudah. Walau kadang kegiatan belajarmengajar seringkali dianggap kegiatan mudah dan biasa-biasa saja. Akan tetapi nyatanya kegiatan belajar-mengajar adalah kegiatan yang komplek dan rumit dengan mengunakan cara-cara atau metode 
pembelajaran tertentu. Menurut Triswanti (2017:179), metode pembelajaran ialah suatu cara agar apa yang dirancang tercapai sesuai harapan

Pengertian lainnya mendefinisikan ini sebagai bentuk pembelajaran yang terurai secara berurutan mulai pembuka sampai penutup. Pendidik akan mencari, menentukan, menyesuaikan atau membuat pelaksanaan pembelajaran yang tepat supaya tercipta kegiatan belajar mengajar yang kondusif. Keefektifan ini dikatakan suatu kegiatan pembelajaran yang mampu menarik minat siswa, memotivasi siswa, memudahkan siswa memahami apa yang disampaikan dan membuat siswa merasa senang untuk belajar. Namun kesalahan dalam kegiatan pembelajaran akan bersifat buruk dan merupakan kesalahan yang fatal.

Kesalahan pemilihan metode pembelajaran, bahan materi dan sebagainya, akan berujung pada kegagalan siswa untuk menerima pesan yang hendak disampaikan guru. Salain itu, membuat siswa merasa bosan, membuat siswa menjadi pasif, dan bisa juga membuat siswa menjadi tidak kondusif. Oleh sebab itu, harus menyesuaikan terlebih dahulu dengan materi yang disampaikan. Penyesuaian materi ini dilakukan supaya tujuan sebelumnya tercapai dengan baik. Tujuan-tujuan pembelajaran mengacuh pada standar nasional yang telah ditetapkan pemerintah dalam beberapa satuan yang tertuang dalam standar isi.

Terutama meteri yang akan dibahas adalah struktur puisi dan itu semua tertuang dalam kurikulum yang digunakan pada saat ini yaitu 2013 yang mengacu keaktifan siswa. Kurikulum ini menggali/membangun pemahaman dan kemampuan siswa dalam beberapa kemampuan. Salah satunya adalah memahami struktur puisi. struktur menulis puisi adalah salah satu unsur pembangun puisi yang sangat penting diperhatikan. Seperti diketahui sekarang ini, kemampuan analisis puisi siswa masih bisa dikatakan rendah. Siswa kurang dalam memahami kata-kata, menentukan diksi, dan rima yang dibaca. Bahkan analisis puisi 
menjadi tugas yang sangat sulit dan tidak disukai sebagian siswa.

Jadi untuk mengatasi hal ini, salah-satu cara yang tepat untuk digunakan dalam mestimulus siswa saat menganalisis atau menentukan struktur puisi adalah menyesuaikan pembelajaran dengan materi. Adapun puisi diteliti adalah Kumpulan Puisi Sesudah Zaman Tuhan. Penulis memilih kumpulan puisi tersebut karena pada saat ini kondisi dialami oleh setiap orang terutama siswa, yaitu Covid 19. Jadi, penelitian yang dilakukan tidak diterapan secara langsung ke sekolah, tetapi mengarah pada penerapan terhadap pembelajaran di sekolah.

Kosasih (2012:97-109) berpendapat bahwa struktur puisi terdiri dari struktur fisik dan struktur batin. Adapun unsur-unsur yang termasuk dalam struktur fisik puisi yakni diksi, pengimajian, kata kongret, bahasa figuratif, rima/ritma, tata wajah. Sebaliknya, struktur batin yaitu tema, perasaan, nada, suasana, dan amanat.

\section{Struktur Fisik}

Diksi berarti memilah kata baik itu makna, susunan bunyi, maupun hubungan antarkata setiap larik dan bait. Kata-kata memiliki kedudukan yang sangat penting dalam puisi. Kata-kata dalam puisi bersifat konotatif dan memiliki lambang. Maknanya pun lebih dari dari satu. Oleh sebab itu, wajib memilih kata berorientasi keindahan.

Pemilihan kata berkaitan dengan puisi yang ditulis secara padat. Oleh karena itu, penyair harus ahli memfilter tiap kata. Tujuannya agar komposisi bunyi rima dan irama memiliki kedudukan sesuai dan terdengar indah (Kosasih, 2012:97).

Imaji merupakan kata atau susunan yang menimbulkan khayalan atau imajinasi. Dengan pengimajian tersebut, pembaca seolah-olah merasakan, mendengar, atau menyaksikan yang dituliskan penyair. Dengan kata-kata itu, pembaca seolah-olah mendengar suara yang didengar penyair, melihat benda-benda yang dilihat penyair, dan meraba atau menyentuh bendabenda yang diraba atau disentuh penyair (Kosasih, 2012:100). 
Gani (2004:21) mengatakan bahwa imajinasi adalah kata atau susunan kata yang mengungkapkan pengalaman indrawi seseorang. Seperti bayangan suatu penglihatan, pendengaran, penciuman, dan perasaan. Jadi dapat disimpulkan dari pengertian diatas bahwa citraan (pengimajinasian) dibagi menjadi 3 bagian yakni: (1) imaji audiktif, (2) imaji visual, dan (3) imaji taktil

Untuk menstimulus imajinasi pembaca, setiap kata diperkonkret, dibayangkan dengan jelas apa yang akan diuraikan (Kosasih, 2012:103). Selain itu, Gani (2004:21) mengatakan kata nyata adalah kata yang dipilih penyair secara eksplisit dalam mengemukakan persoalan yang disampaikan. Kata-kata tersebut harus ditangkap oleh panca indera. Jadi seiring dengan pengertian-pengertian tersebut dapat disimpulkan bahwa kata konkret berhubungan langsung dengan kemunculan imaji. Hal tersebut disebabkan kata konkret yang bersentuhan dengan kiasan, simbol, atau lambang akan memicu daya imajinasi pembaca.
Majas ialah bahasa khas penyair untuk mengungkapkan sesuatu dengan cara membandingkan dengan benda atau kata lain. Majas mengiaskan atau mempersamakan sesuatu dengan hal lain (Kosasih, 2012:104). Untuk memperoleh kepuitisan, penyair menggunakan bahasa figuratif, yaitu bahasa kiasan atau majas. Adapun macam-macam majas, antara lain metafora, personifikasi, ironi, hiperbola, repitisi.

Rima ialah pengulangan bunyi dalam puisi. Dengan adanya rima atau puisi menjadi lebih indah. Makna yang ditimbulkan menjadi kuat (Kosasih, 2012:104). Selanjutnya, tata wajah (tipografi) merupakan pembeda antara puisi, prosa dan drama. baris-baris puisi tidak berbentuk paragraf, melainkan bait. Dalam puisi-puisi modern seperti karya Sutardji Calzoum Bachri, tipografi dianggap begitu penting sehingga menggeser kedudukan makna kata-kata (Kosasih, 2012:104).

Sementara itu, Gani, (2004:21) menjelaskan perwajahan atau tata wajah adalah tampilan puisi 
sebagai salah satu hasil seni kreatif. Desain puisi tersebut dapat dicermati dalam berbagai bentuk, misalnya: penataan bahasa, penggunaan tanda atau lambang, pengaturan jarak baris, pengaturan letak huruf, kata, baris, atau bait.

\section{Struktur Batin}

Tema merupakan ide pokok yang diungkapkan penyair dalam puisinya. Berfungsi sebagai langkah awal sebelum menulis (Kosasih, 2012:105). Sebaliknya, Gani, (2004:19) berpendapat gagasan adalah pokok permasalahan yang dikemukakan dalam puisi.

Perasaan ialah sikap penyair terhadap pokok persoalan dalam puisinya. Umumnya setiap penyair memiliki pandangan yang berbeda terhadap karya yang akan ditulis. Sejalan dengan pendapat tersebut (Gani 2004:19) mengatakan perasaan atau feeling adalah apresiasi, sikap, atau emosional penyair terhadap pokok permasalahan yang disampaikan di dalam puisi yang ditulisnya. Perasaan-perasaan tersebut bisa berupa takjub, sedih,

senang, marah, heran, gembira, tidak percaya, nasehat, dan sabagainya.

Dalam penulisan puisi, penyair mempunyai sikap tertentu terhadap pembaca: apakah ingin bersikap menggurui, menasihati, mengejek, menyindir, atau lugas menceritakan sesuatu kepada pembaca. Sikap penyair kepada pembaca ini disebut nada (Kosasih, 2012:109). Jadi, nada merupakan refleksi sikap penyair terhadap pembacanya, baik suasana hati, dan pandangan moral, dan terkadang muncul pula karakter kepribadian pengarangnya tercemin dalam puisi.

Amanat yang ingin
disampaikan oleh penyair dapat
ditelaah setelah memahami tema,
rasa, dan nada puisi. Tujuan atau
amanat merupakan hal yang
mendorong penyair menciptakan
puisi. Amanat tersirat dibalik kata-
kata yang disusun, dan berada
dibalik tema yang diungkapkan
(Kosasih, 2012:109).
Setelah memahami struktur
tersebut lalu dihubungkan dengan
kumpulan puisi Sesudah Zaman
Tuhan dengan memperhatikan
kurikulum dan pendapat Hasanudin,


(2015:5) yang menyatakan bahan pembelajaran yang digunakan telah disesuaikan dengan tiga aspek. Tiga aspek tersebut adalah bahasa, kematangan kejiwaaan (psikologis), dan latar belakang budaya. Sejalan dengan itu berarti bahan pembalajaran haruslah komunikatif (bahasa), tepat sasasran (psikologis), dan sesuai kondisi (latar belakang budaya).

\section{METODE PENELITIAN}

Pendekatan dalam penelitian
ini adalah pendekatan struktural.
Penulis memilih pendekatan
struktural menganalisis unsur-unsur
karya sastra. Nurgiyantoro (dalam
Hariningtyas,
mengemukakan bahwa struktur karya
sastra dapat diartikan sebagai
susunan, penegasan dan gambaran
semua bahan dan bagian yang
menjadi komponennya serta secara
bersama membentuk kebulatan yang
indah. Sementara itu, metode yang
digunakan dalam penelitian ini ialah
metode deskriptif kualitatif.
Sumber data berupa
kumpulan puisi Sesudah Zaman

Puisi tersebut dipublikasikan lewat online berupa buku elektronik di website sastra. Kumpulan puisi tesebut bertema wabah covid-19 dan peneliti mengambil 10 sample untuk diteliti. Lalu, peneliti mengkaji puisipuisi tersebut berdasarkan struktur puisi atau unsur-unsur pembangun puisi. Selain itu, data dari informaninforman yakni, dua guru SMP N 1 Indralaya Selatan dan 3 siswa SMP N 1 Indralaya Selatan.

\section{PEMBAHASAN}

Hasil penelitian tentang struktur puisi pada kumpulan puisi Sesudah Zaman Tuhan. Pertama, diksi yang digunakan penyair dalam puisi-puisi tersebut terdiri dari katakata puitis atau diksi konotatif. Namun ada sebagian puisi juga menggunakan kata-kata yang jelas dan seperti bahasa kesaharian atau denotatif.

Pemilihan kata-kata tersebut
pun sangat efektif untuk
mengomunikasikan pesan penyair
atau maksud penyair kepada
pembaca. Kata-kata yang mudah
dipahami dengan menggunakan
kosakata yang familiar pada setiap


kalangan masyarakat terutama siswa SMP. Selanjutnya, citraan dalam puisi biasanya terdapat beberapa macam citraan yaitu, (1) imaji suara (2) imaji penglihatan, dan (3) imaji raba atau. Citraan ini terdapat pada setiap puisi karena penyair mengajak pembaca untuk merasakan apa yang dirasakan oleh penyair. Merasakan sentuhan yang dirasakan oleh penyair, melihat apa yang dilihat penyair, dan mendengar apa yang didengar oleh penyair. Penyairpenyair dalam puisi ini menggunakan citraan yang sangat jelas dan sangat mudah untuk diterima dan dirasakan oleh pembaca buku. Hal tersebut karena dalam puisi-puisi tersebut berisikan citraancitraan yang berlatar sama dengan pembaca. Kondisi pada citraan puisi semuanya berkaitan dengan covid-19 yang mana pada saat ini kondisi inilah yang dirasakan oleh semua orang terutama siswa.

Selanjutnya, kata konkret biasanya digunakan oleh penyair dengan tujuan agar pembaca dapat membayangkan kehidupan yang dimaksud oleh penyair. Kata konkret dalam puisi pada kumpulan puisi
Sesudah Zaman Tuhan mampu megkonkretkan arti dari puisi. Hal itu disebabkan penggunaan bahasabahasa yang sangat jelas dan langsung tertuju pada istilah-istilah tentang covid-19 yang mudah dipahami. Selanjutnya, bahasa figuratif atau majas digunakan oleh penyair pada puisi-puisi bertujuan untuk mengatakan atau nyampaikan sesuatu dengan cara pengiasan, yakni tidak langsung menggungkapkan makna. Hal tersebut dapat ditemukan dari penggunaan majas oleh penyair. Majas yang digunakan penyair dalam puisi terdiri dari personifikasi, hiperbola, dan repetisi. Penyair dalam kumpulan puisi sesudah zaman tuhan sajak dari masa covid19 mengunakan bahasa kiasan yang mudah dipahami oleh setiap orang.

Rima/ritma atau persamaan bunyi dalam puisi. Pada umumnya puisi-puisi ditulis dengan menggunakan rima akhir, tetapi ada juga rima lain seperti rima awal, rima campuran dan lain-lain. Puisi dalam kumpulan puisi Sesudah Zaman Tuhan sering sekali ditemukan rima. Puisi-puisi dalam kumpulan puisi sesudah zaman tuhan ini sangat 
memperhatikan penggunakan rima atau ritma disamping puisi yang indahnya diksi, majas bermakna dalam, dan citraan yang tepat.

Tata wajah atau tipografi pada puisi dalam kumpulan puisi sesudah zaman tuhan semuanya menggunakan tata wajah yang beragam-ragam bahkan berpola. Tata letak larik pun semuanya berada pada sebelah kiri lembar kerja atau kertas puisi. namun ada dua puisi yang mengunakan tata wajah yang berbeda seperti pada puisi yang berjudul "Covid-19: Sajak Terakhir Sebelum Punah" karya Aslan Abidin yang menata puisinya dengan beratakan yang mana tata letak ini mengartikan bahwa keadaan atau kondisi yang diakibatkan Covid-19 adalah kekacauan atau kekahancuran sehingga dunia menjadi berantakan.

Selain itu, ditemukan pada puisi yang berjudul "Social Distancing" karya Dedy Tri Riyadi yang membuat bait dengan huruf yang berjarak satu spasi yang mengartikan pada saat ini setiap orang harus menjaga jaraknya supaya terhindar dari virus corona. Ada satu larik dari bait pertama yang ditulis miring yang memberikan kesan penekanan. Pada puisi tersebut penyair menekankan bahwa sekarang manusia masuk ke dalam dunia maya atau dunia virtual.

Tema pada puisi dalam kumpulan puisi sesudah zaman tuhan tergolong atau bertopik covid-19 dengan ada beberapa kondisi yang membagi temanya menjadi beberapa bagian. Ada yang bertema Pemerintah lebih mementingkan keuangan dari pada kesehatan, pandemi covid-19 yang membantai manusia, perubahan pola hidup dan keterbatasan beraktivitas akibat covid-19 dan lain-lain. Selanjutnya, perasaan merupakan ungkapan perasaan penyair dalam setiap barisbaris puisinya. Perasaan berkaitan dengan nada yang digunakan penyair dalam puisinya. Misalnya ketika penyair menggunakan nada belas kasih, pembaca dapat mengetahui rasa sedih penyair melalui kata-kata. Perasan penyair pada puisi dalam kumpulan puisi sesudah zaman tuhan terdiri dari perasaan takut, waspada, sedih, pasrah, rindu. Perasaan penyair tersebut juga diraskan oleh pembaca karena pada saat ini semua 
kalangan merasakan derita yang disebabkan oleh covid-19.

Selanjutnya, yang terakhir yaitu nada. Nada merupakan sikap penyair dalam puisi-puisinya. Penggunaan nada puisi tersebut dimaksudkan supaya menimbulkan suatu suasana tertentu yang hendak disampaikan penyair. Nada tersebut beragam seperti belas kasih, menasihati, mengurui, serius, mengejek dan lainya. Penyair pada puisi dalam kumpulan puisi sesudah zaman tuhan mengunakan beberapa nada di antaranya nada, mencekam, menasihati, mengkritik, mengingatkan, bercerita, dan tegar. Kesepuluh, amanat yang diselipkan penyair dalam puisinya tidak terlepas dari tema dan isinya. Amanat yang terkandung Sesudah Zaman Tuhan disampaikan secara jelas sehingga pesan amanat tersampai secara baik kepada pembaca.

Pernyataan-peryataan di atas menunjang puisi-puisi dalam kumpulan puisi Sesudah Zaman Tuhan untuk menjadi materi pembelajaran dan bukan hanya sebatas bacaan sastra semata. Beberapa hal yang menjadi pertimbangan menentukan materi pembalajaran menurut Hasanudin, (2015. h. 5). adalah bahasa, kematangan jiwa (psikologi), dan latar belakang budaya. Sejalan dengan itu berarti bahan pembalajaran haruslah komunikatif (bahasa) yang mana terlihat pada puisi-puisi dalam Kumpulan Puisi sesudah zaman tuhan sajak dari masa covid-19. Bahasa-bahasa yang digunakan dalam puisi-puisi tersebut adalah bahasa yang familiar, sehingga peserta didik terutama SMP dapat dengan mudah memahami puisi tersebut.

Selanjutnya tepat sasaran (psikologis), puisi-puisi dalam Kumpulan Puisi sesudah zaman tuhan sajak dari masa covid-19 berisi tentang pandemi covid-19 yang mana secara global dirasakan oleh seluruh orang termasuk siswa SMP. Keluh-kesah atau perasaan penyair terhadap keadaan yang dilandah pandemi covid-19 juga dirasakan oleh siswa SMP sehingga secara psikologis puisi-puisi tersebut cocok untuk siswa. Kemudian sesuai dengan kondisi (Latar belakang budaya), puisi-puisi dalam 
Kumpulan Puisi sesudah zaman tuhan sajak dari masa covid-19 ditulis oleh penyair-penyair Indonsesia yang mempunyai kondisi yang sama dengan siswa SMP. Kondisi yang dimaksudkan adalah peristiwa kehidupan yang tuliskan oleh penyair adalah peristiwa yang mereka alami sekarang dan secara tidak langsung juga dialami oleh siswa SMP yaitu merasakan dampak pandemi covid-19.

Hal tersebut akan menumbuhkan minat siswa untuk membacanya karena siswa merasa hal yang dirasakan penyair. Peryataan ini diperkuat oleh pendapat Wasilaturrahmi, S.Pd. seorang guru di SMP N 1 Indralaya Selatan yang mengatakan pembalajaran menganalisis puisi masih ditemukan kendala pada materi yang digunakan. Puisi-puisi yang digunakan dalam pembelajaran analisis puisi tidak sesuai dengan kondisi dan lingkungan siswa. Siswa lebih cendrung menyukai puisi-puisi yang sesuai dengan lingkungan dan kondisi mereka dengan bahasanbahasan yang mudah dipahami. Beliau juga mengatakan bahwa puisi-puisi dalam Kumpulan Puisi sesudah zaman tuhan ini sesuai bila dijadikan materi pembalajaran. Puisipuisinya sesuai dengan latar belakang siswa dan merupakan puisi yang temanya atau bahasannya terbilang masih panas atau baru, serta mencerminkan kehidupan yang mereka alami. Beliau juga menyakini bahwa puisi-puisi ini akan menarik minat baca siswanya karena cara bacanya yang mudah yaitu cukup menggunakan smartphone dan isi puisinya yang menarik.

Hal senada juga diungkapan oleh Dewi Shintawati, S.Pd. seorang guru dari SMP N 1 Indralaya Selatan yang menyatakan pembalajaran struktur puisi di SMP masih perlu dibenai. Beliau menjelaskan masih ada sebagian siswa yang kurang berminat belajar menganalisis struktur puisi. Sebagian siswa cendrung merasa jenuh dengan puisipuisi lama yang ada dalam buku materi pembalajaran mereka. Bahkan ada yang tidak memahami beberapa istilah yang menurut mereka sungkar untuk dimaknai. Beliau berpendapat bahwa ada beberapa siswanya tidak mampu membayangkan apa yang 
dimaksud penyair karena mereka tidak mengenal kondisi dan situasi yang dialami penyair. Beliau juga mengatakan bahwa puisi-puisi dalam Kumpulan Puisi sesudah zaman tuhan sangat sesuai dengan bila dijadikan materi pembalajaran puisi. Menurut beliau puisi-puisi tersebut sangat jelas kata konktret yang penyair sampaikan, sehingga siswa tidak akan merasa kesulitan untuk memaknainya. Selain itu, beliau mengatakan tema-tema dan amanat dalam puisi-puisi tersebut sangatlah baik, tema tentang agama, kritik sosial dan pemerintah, serta amanat yang memuntun siswa untuk berprilaku terpuji menambah kesesuaiannya untuk dijadikan materi pembalajaran.

Wila Rahma Ayu seorang siswa kelas 9.1 SMP N 1 Indralaya Selatan berpendapat bahwa pembelajaran puisi di sekolah sangat membosankan. Guru meminta siswa membaca puisi yang ada di buku pokok dan LKS yang merupakan karya-karya penyair lama yang kerap ia tidak mengerti dan tidak mampu menarik makna dan pesan yang terdapat pada puisi tersebut. Ia juga berpendapat bahwa puisi-puisi dalam Kumpulan Puisi sesudah zaman tuhan berisikan larik-larik yang dapat ia mengerti dan dapat mengetahui makna dari setiap kata pada puisipuisi tersebut.

Devi Syahputri siswa kelas 9.4 SMP N 1 Indralaya Selatan mengatakan guru sering sekali menyuruh menghafal teori-teori tentang puisi dan membaca puisipuisi lama yang membuatnya jenuh. Ia juga berpendapat bahwa puisipuisi dalam Kumpulan Puisi sesudah zaman tuhan sangat menarik minat bacanya karena bisa dibaca dimana saja melalui Hp. Pendapat yang senada juga disampaikan oleh Mareta Mandira siswa kelas 9.3 SMP N 1 Indralaya Selatan yang mengatakan pembelajaran puisi tidak menyenangkan dan malah membingungkan karena menggunakan contoh-contoh puisi lama seperti karya-karya Thaufik Ismail dan Chairil Anwar yang sulit di pahami. Sedangkan, saat ia membaca puisi-puisi dalam kumpulan puisi Sesudah Zaman Tuhan sajak dari masa covid-19 ia dengan mudah memahani kata-kata 
dan keadaan pada puisi-puisi tersebut.

Berdasarkan pendapat di atas disimpulkan bahwa sebagian besar puisi Sesudah Zaman Tuhan layak dijadikan sebagai bahan pembalajaran bahasa Indonesia dan sastra Indonesia, khususnya struktur puisi pada jejang SMP. Alasannya puisi-puisi itu menggunakan kata konkret yang mudah dipahami dan sesuai dengan psikologis atau kejiwaan siswa yang sekarang dilanda pandemi covid-19 yang merasakan bagaimana keterbatasan beraktivitas.

Di samping itu, puisi-puisi dalam kumpulan puisi sesudah zaman tuhan memilki tema yang mengajak berbuat kebaikan dan membentuk pribadi siswa menjadi lebih baik. Bila dikaitkan dengan kurikulum 2013 revisi 2016 struktur puisi juga terdapat di kelas VIII pada kompetensi dasar 3.8 Menelaah unsur-unsur pembangun teks puisi (Perjuangan, lingkungan hidup, kondisi soisal, dan lain-lain) yang diperdengarkan atau dibaca. Berarti secara tidak langsung hasil penelitian ini bisa digunakan sebagai materi pembalajaran menelaah unsur-unsur penbangun puisi atau struktur puisi. Selain itu, silabus tersebut memuat teks puisi yang mengandung tema tentang kondisi sosial dan lingkungan hidup yang merupakan tema yang selaras dengan tema dari puisi-puisi dalam Kumpulan Puisi sesudah zaman tuhan .

Hal tersebut mempertegas kelayakan sebagian besar puisi-puisi tersebut untuk dipelajari atau diterapkan pada pembalajaran analisis puisi di SMP. Sejalan dengan peryataan tersebut, peneliti akan menyusun RPP untuk pembelajaran analisis puisi berdasarkan hasil penelitian. Peneliti akan membuat RPP yang sesuai dengan kurikulum 2013 dengan memperhatian KI, KD, Indikator, tujuan, materi pembalajaran, model dan metode pembalajaran, serta media yang digunakan. KI atau kompentensi inti sangat sesuai dengan puisi-puisi Kumpulan Puisi sesudah zaman tuhan karena amanat dan isi dari puisi ini akan menuntun siswa untuk merealisasikan KI yang terdiri dari empat bagian. 
Sebagai salah-satu contoh puisi yang sesuai dengan KI, puisi yang berjudul "Pasca Wabah" Karya Arif P. Putra dengan amanat "jangan hanya meminta tetapi selalu berdoa dan sertai sembayang supaya doa-doa dapat terkabul". Amanat tersebut mampu merealisasikan $\mathrm{KI}$ yang pertama yakni, menghargai dan menghayati ajaran agama yang dianutnya. Selanjutnya, isi puisi "Pasca Wabah" menggunakan bahasa yang baik dan santun yang secara tidak langsung membimbing siswa untuk menggunakan bahasa yang santun. Hal tersebut juga tercantum dalam KI bagian kedua yakni, menghargai dan menghayati prilaku jujur, displin, santun dan lain-lain.

\section{SIMPULAN}

Kesimpulan bahwa struktur fisik puisi dalam kumpulan puisi Sesudah Zaman Tuhan, yaitu pertama, diksi yang digunakan oleh penyair adalah diksi konotatif atau kata-kata puitis dan memperhatikan pemilihan kosakata yang mudah dipahami siswa. Kedua, Citraan yang ditemukan pada puisi-puisi tersebut terdiri dari tiga citraan yaitu imaji visual, imaji audiktif, dan imaji Tektil yang terasa nyata karena kondisi yang dialami siswa sama dengan citraan puisi.. Ketiga, kata konkret yang digunakan puisi-puisi tersebut merupakan kata konkret yang mudah dipahami sehingga pembaca mudah memahami isi puisi.

Struktur fisik puisi yang keempat, bahasa figuratif yang ditemukan pada puisi-puisi tersebut meliputi Majas Personifikasi, majas hiperbola, dan majas repetisi. Kelima, rima yang ditemukan pada puisi-puisi tersebut meliputi rima awal dan rima akhir. Keenam, tata Perwajahan yang ditemukan adalah tata perwajahan konvensional dan ada tata perwajahan yang menulis puisi secara tidak teraktur dan juga ada yang berspasi

Struktur batin pada puisipuisi dalam kumpulan puisi "Sesudah Zaman Tuhan" sebagai berikut: pertama, tema yang ditemukan pada puisi-puisi dalam kumpulan puisi "Sesudah Zaman Tuhan"meliputi, religius, kritik sosial, kritik pemrintah, ketakutan, rindu yang beraitan langsung covid- 
19. Kedua, Perasaan yang ditemukan pada puisi-puisi dalam kumpulan puisi "Sesudah Zaman Tuhan"meliputi perasaan takut, rindu, nasihat, sedih dan lainya. Ketiga, nada yang ditemukan pada puisi-puisi dalam kumpulan puisi “Sesudah Zaman Tuhan"adalah nada mencekam, menasihati, tegar, dan menginggatkan. Keempat, amanat yang ditemukan pada puisi-puisi dalam kumpulan puisi "Sesudah Zaman Tuhan" berupa mengajak berbuat kebaikan dan membentuk karakter siswa menjadi lebih baik.

Hasil penelitian di atas telah menyatakan bahwa sebagian besar puisi-puisi dalam kumpulan puisi "Sesudah Zaman Tuhan"sesuai untuk dijadikan materi dan bahan pembelajaran analisis puisi pada mata pelajaran bahasa dan sastra Indonesia di SMP. Peryataan tersebut juga selaras dengan data dari informan-informan yang mengatakan puisi-puisi dalam kumpulan puisi "Sesudah Zaman Tuhan" susuai menjadi materi pembelajaran analisis puisi pada mata pelajaran bahasa dan sastra Indonesia di SMP.

\section{SARAN}

Saran bagi pembaca yaitu harus banyak membaca karya sastra terutama puisi, karena banyak sekali ilmu yang didapat dengan membaca puisi dan juga banyak cerminan hidup yang terkandung dalam puisi. Selanjutnya, bagi guru bahasa Indonesia hasil penelitian dapat dimanfaatkan sebagai contoh dalam mengkaji struktur yang ada di dalam puisi. Selain itu,puisi-puisi dalam kumpulan Puisi Sesudah Zaman Tuhan sebagai alternatif materi pembelajaran struktur puisi di SMP.

\section{DAFTAR PUSTAKA}

Gani, Erizal. 2014. Kiat membaca Puisi : Teori dan Terapan. Bandung: Pustaka Reka cipta.

Hariningtyas, Ervin. 2011. Analisis Struktur Kumpulan Puisi Aku Ini Puisi Cinta Karya Abdurahman Faiz Dan Kesesuaiannya Sebagai Materi Pembelaja-ran Apresisasi Puisi Jenjang SMP. Suryakarta:

Perpustakaan.uns.ac.id

Hasanudin, Puput. 2015. Kajian Sosiologi Sastra Novel Memang Jodoh Karya Marah Rusdi dan pembelajarannya di SMA. Perowejo: Surya Bahtera. 
Kokasih, E. 2012. Dasar-Dasar Keterampilan Bersastra. Bandung : Yrama Widya

Ratna, Nyoman Kutha. 2016. Stilistika kajian puistika bahasa, sastra, dan bahasa. Yogjakarta: Pustaka Pelajar

Triswanti, Endah. 2017. Pengaruh Metode Pembelajaran Inkuiri Terhadap Hasil Belajar Praktik Kewirausahaan
Ditinjau Dari Tingkat Kognitif Siswa. UHAMKA : Jurnal penilitian dan penilaian pendidikan FEPI.

Widowati, Dewi. 2012. Efek media massa terhadap Khalayak. Jakarta : STIE IPWIJAYA

Wirawan, gunta. 2016. Analisis Struktural Antologi Puisi Hujan Lolos Di Sela Jari Karya Yudhiswara. Singkawang: STKIP 